\title{
China and the Film Festival
}

\author{
RICHARD PEÑA
}

I find the recent emergence of the film festival studies subfield, alongside a number of historical surveys and critical texts, rather intriguing. One could say, Why not? The festival indeed has become an institution of sorts, as much as the film archive or even the film studio, and can trace a history of film festivals that will soon be one hundred years old. The festival influenced patterns of exhibition and, in many cases, made a decisive impact on film culture. Yet I guess as someone who worked "in the trenches" for twenty-five years, I find it amusing to read somewhat long-winded analyses around decisions of what to show or exhibition structure when so often those decisions are the result of far more mundane preoccupations, such as the availability of a director or a venue.

Festivals, defined crudely as collections of films presented at a given place and time, began to evolve in the 1920s in Europe, as groups of what might be called independent filmmakers would occasionally gather and show work that was considered nontraditional or at least noncommercial. But the emergence of the festival proper usually dates back to 1932, with the introduction of a film section as part of the Venice Biennale. Very much promoted by Il Duce's movie-obsessed son Vittorio Mussolini, the Venice program, despite its obvious glamour and chic, continued a theme that had been present in those first festivals organized by independents: the film festival as protest, as the creation of an alternative space for exhibition, and promotion of a cinema that was not Hollywood commercial production. Hollywood, of course, completely dominated world film exhibition, even after the coming of synchronized sound cinema; there had been a number of efforts to compete with that hegemony, especially in Europe, from the promotion of "national film styles" such as German expressionism to the notion of "Film Europe," a series of economic agreements among nations that would try to treat all of Europe as one big filmmaking region, an idea that has had renewed currency since the nineties. The creation of a film festival was yet another: if the nations of the world could send their finest films to a competition in which Hollywood would simply be another participant, the resulting publicity could perhaps raise awareness and open markets to non-Hollywood films.

The economic and political turbulence of the thirties discouraged other festivals from emerging - the first Cannes festival was scheduled to begin on September 2, 1939; that is, the day after the Germans invaded Poland and triggered World War II in Europe-but in the years right after the war, they proliferated rapidly: Cannes and Locarno in 1946, 
Edinburgh in 1947, and Berlin in 1950. By the late fifties, most decent-sized cities had developed or were developing their own festivals. Yet this new breed of festivals-such as Pesaro, New York, or Rotterdam—had a somewhat different character: the idea of festivals as reflection of the taste and political/aesthetic positions of their organizers. Until the late sixties, many of these festivals were actually assembled by requesting participating countries to submit a film; there was little independent curating. Festivals might still be offering a kind of alternative to Hollywood — by the fifties there were many of them—but now they were also being used for something else: for the projection of national identity and culture. Films represented not only themselves and their organizers' visions; they also, it was proposed, represented something like a national ethos. After the extensive involvement of governments around the world in promoting national filmmaking in the thirties and, of course, during the war, this promotion of films as representing nations might be seen as a somewhat logical next step. Indeed, one can point to a marked rise in cinematic nationalism after World War II, during which so many countries featured not only impressive growth of their production numbers but also a new desire to make sure their histories and cultures would be represented. My own history as a film-culture bureaucrat, first as the director of the Film Center at the Art Institute of Chicago, now known as the Gene Siskel Film Center, and then at Lincoln Center, very much paralleled the emergence of Chinese cinema into the consciousness and on to the screens of US filmgoers. Prior to coming to work in Chicago, I was barely acquainted with Chinese cinema: in college, I had seen that cultural-revolution classic Breaking with Old Ideas (决裂, Li, 1975; see figure 1), as well as a few examples of wuxia films in Chinatown theaters.

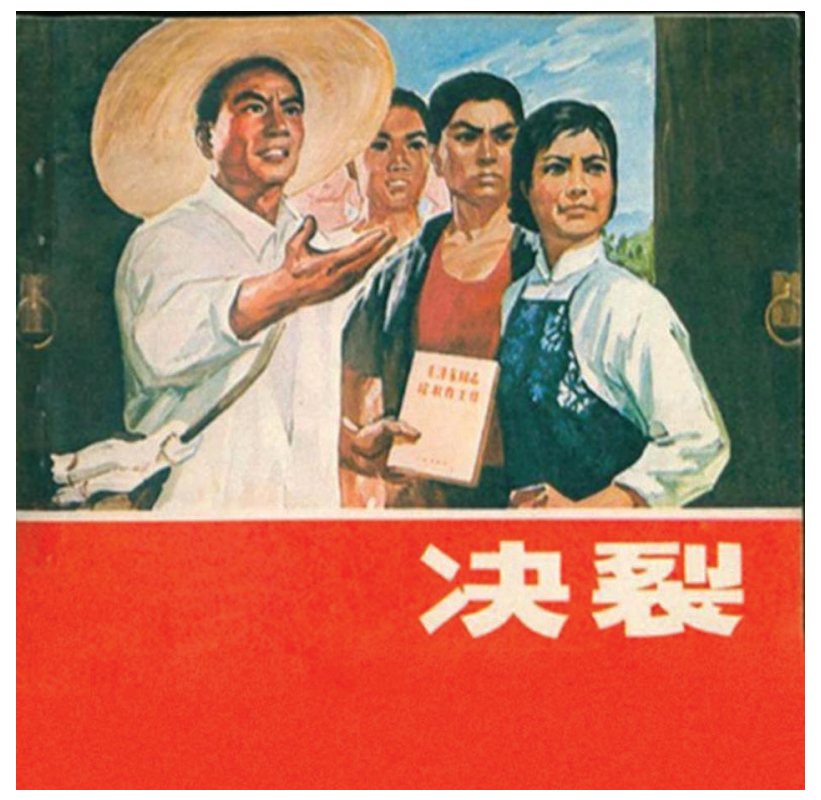

Figure 5.1: Poster of Breaking with Old Ideas.

Source: fair use 
Sadly, I had missed the famous screening of King Hu's Touch of Zen (俠女, 1971) at the New York Film Festival (NYFF). Thus, I was delighted to have the chance to see what Chinese filmmakers had been up to when one of my first duties in Chicago was to supervise the very first traveling film series from the People's Republic of China (PRC) in 1980 - the United States had just established diplomatic relations, and we exchanged films. The package we sent included Bambi (Hand, 1942) and Singin' in the Rain (Kelly and Donen, 1952). One of the films in the Chinese film package that sounded intriguing was something called Two Stage Sisters (舞台姐妹, Xie, 1964; see figure 2).

I had seen and enjoyed Chinese opera a few times, so a film on the subject seemed intriguing. Moreover, Madame Mao has labeled the film a "poisonous weed," so what better recommendation?

At the end of the screening, I could hardly get up from my seat. As any artistic masterwork should, the film stunned me, but what kept me immobilized was the realization that this great, great film was completely unknown outside of China. I searched in vain for references to it or to its director; I found none. That such an extraordinary

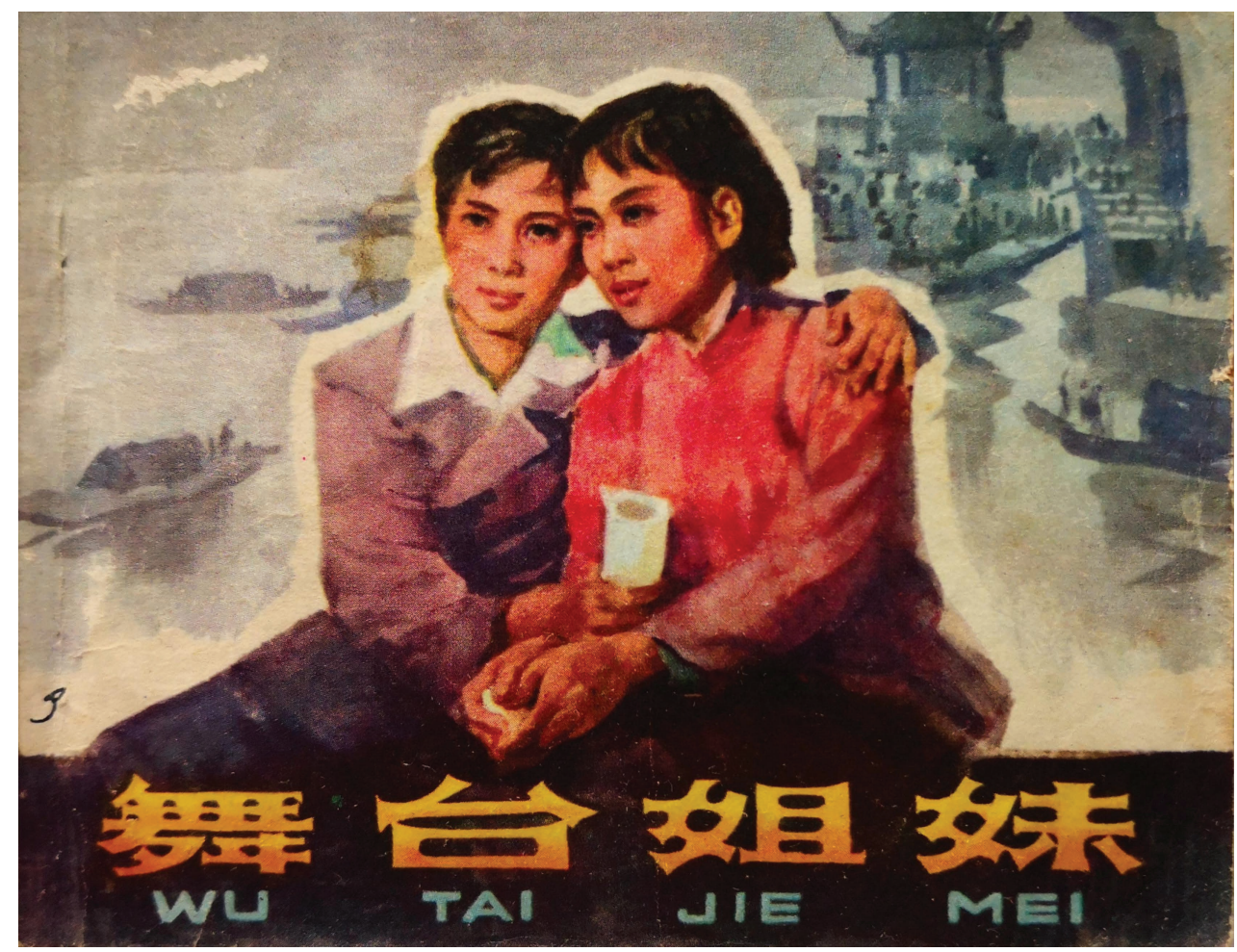

Figure 5.2: Poster of Two Stage Sisters. Source: fair use

1. I first read Mao's description in a brochure for a series, Electric Shadows: Early Chinese Cinema, presented in 1979 by the San Francisco Film Festival and curated by Stephen Horowitz. 
work — and the impressive level of production that had made it possible—should exist completely outside of the purview of even the most dedicated filmgoers in the United States powerfully illustrated how little about film history we actually knew. Two Stage Sisters was simply too good to exist on its own. It would have emerged from a fertile cinematic tradition and been the product of strong artistic vision. So over the next decade, learning about Chinese cinema first became an interest for me and then a passion, both of which I could indulge somewhat through my work at the Film Center. One could argue that Chinese cinema very much dominated the entire field of museum and archival programming in the eighties, with retrospectives of older films, dedicated issues of leading film magazines, and of course the remarkable new films and filmmakers who began to emerge from Taiwan, Hong Kong, and the PRC (the fifth generation). I had always envied those critics and scholars who had been around for the Western discovery of Japanese cinema in the fifties, and now I had the chance to experience some of the same exhilaration with Chinese cinema. It was as if a giant treasure chest had suddenly been flung open for all of us and we couldn't unpack its offerings fast enough.

In 1988, I moved back to New York to work at Lincoln Center; now, I was in an even better position to indulge my growing interest in Chinese cinema. The NYFF, which would occupy a large part of my work, had been an enormous influence on my life and thinking about cinema, and I believe it's had a similar effect on US film culture over the years. To understand what you might call the ethos of the NYFF, you must return to the year it was founded: 1963. The inaugural NYFF pioneered a new style of the "curated film festival." Rather than request and accept entries from around the world, the festival organizers made their own choices, after traveling to other festivals or inviting films in for consideration. Two critical tendencies that were influential at that moment were also decisive in setting the festival's direction: auteurism and modernism. Film Culture had just published Andrew Sarris's hugely influential article "Notes on the Auteur Theory" in 1962. Not only did scholars begin applying the notion of the cinematic auteur retroactively to the great artists of classic Hollywood but, more importantly for the festival, they proactively applied the label to a small group of contemporary film directors-Jean-Luc Godard, Bernardo Bertolucci, Miklós Jancsó, Nagisa Ōshima, Luis Buñuel, John Cassavetes, Agnès Varda—with whom the festival very quickly became identified. These were artists not only making personally expressive works but they also saw themselves in dialogue with other contemporary arts and artists. Indeed, one could say the NYFF has been a quintessential auteurist program, its small size generating the sense that festival appearances, for better or worse, constituted membership in an elite club.

The festival's commitment to the idea of cinematic modernism emerged from a kind of a split in the foreign films being shown in the United States. The fifties had opened 
US markets to international cinema and thus audiences were enjoying Japanese samurai films, Italian comedies, and French literary adaptations, but audiences for foreign films began to fragment in the 1960s with films such as La Dolce Vita (Fellini, 1960), À bout de souffle (Jean-Godard, 1960), Hiroshima mon amour (Resnais, 1959), and L'Avventura (Antonioni, 1960) on offer. The NYFF was founded partly as a way of defending and creating a platform for this new, more difficult cinema that challenged the practices and conventions of what we now call classical cinema.

When I arrived at Lincoln Center in 1988, these two pillars were still very much in place even though many of the auteurs who made the festival's reputation no longer worked, or worked less, and something called postmodernism actively challenged the principles of cinematic modernism. Of course, I wanted to introduce the new Chinese cinema that I had already been promoting in Chicago to the festival; frankly, the NYFF had been slow in noticing all that was happening in Asia at that time, especially compared to other festivals. Both Hou Hsiao-hsien had appeared already in the festival, and both Hou and Edward Yang had shown in the New Directors/New Films program copresented by Lincoln Center and the Museum of Modern Art. Jackie Chan himself had made a festival appearance with Police Story (警察故事, Chan and Chen, 1985) in 1986, helping launch a wave of interest in his work. New Directors/New Films had also presented a number of fifth generation films, notably Yellow Earth (黄土地, Chen, 1984) and The Horse Thief (黄土地, Tian, 1986).

Perhaps, not surprisingly, the festival and indeed the critical community found a way of approaching Chinese cinema through the aforementioned filters of auteurism and modernism. In that sense, both the PRC's fifth generation and the Taiwanese New Wave were tailor-made for the auteurist narrative: in each case, ambitious young directors were seen as breaking free of the traditions and stereotypes that had dominated their respective cinemas and had instead developed their own cinematic approaches that dialogued with contemporary approaches found in other countries. The fifth generation also took on the mantle of being dissidents of a sort, creating works that chafed against what we thought was the weakening communist ideology imposed by the state. The new cinema of the PRC and Taiwan, which by the late eighties had become staples not only of the New York Film Festival but of festivals around the world, came readymade with a selection of discernible auteurs whose works could immediately fit into a certain kind of critical structure.

Curiously, Hong Kong cinema was the outlier. By the late 1980s, John Woo, and perhaps Ringo Lam, stood out as auteurs, but their bodies of work seemed overly tied to genre-wonderfully made and often innovative but less "personal" in the sense promoted by proponents of auteurism. We'd have to wait for Wong Kar-wei to appear on the scene for Hong Kong to have its first internationally recognized auteur in the traditional sense. Earlier interest in the films of Allen Fong or Ann Hui such as Ah Ying 
(半邊人, Fong, 1983) or Boat People (投奔怒海, Hui, 1982) never really coalesced, and their subsequent films garnered even less interest.

The interest in Hong Kong films seemed to follow the other option: modernism. In what ways could Hong Kong cinema, either in its wuxia or gunplay varieties, be read back through the ideas about modernism that had been so important to both European and US discourses on film? How were we to see the deliberate flouting of the conventions of time and space seen so often in the films, as well as their marked tendency toward presentation instead of representation? While new waves from France to Brazil were struggling to come up with film styles alternative to that of classic Hollywood, had the Hong Kong filmmakers somewhat effortlessly invented their own and within a commercial context? Indeed, the growing awareness of Chinese (and later Japanese and South Korean) cinema called into question many of the ideas of modernism that had become somewhat institutionalized in the United States. Many of the stylistic tendencies seen in these films- the lightning-speed montages that burst into the films of King $\mathrm{Hu}$ or the staid, austere camera of Yasujiro Ozu-were in fact much less disruptions of some classical film style than the expression of these filmmakers' deep roots in very traditional ideas about artistic practice.

Finally, where did this leave audiences? Although New York Film Festival audiences are as adventurous as any, the overall arthouse audience has, without a doubt, grown more conservative; perhaps as they aged, its members liked being challenged less than when they were in college. These changing preferences created a divergence in the auteurist tendencies I mentioned earlier with regards to the Chinese fifth generation and the Taiwanese New Wave. Rather quickly, PRC filmmakers, especially Zhang Yimou, found in the historical spectacle a form that provided both the necessary exoticism as well as familiar narrative frameworks. For whatever reasons-most probably because they truly were auteurs, dedicated above all else to self-expression-Taiwanese directors created works that were simply too off-putting, too hermetic to penetrate the defenses for US audiences. Even Hou's Flowers of Shanghai (海上花, 1998), although enormously praised for its plastic beauty, told too obscure a story to appeal to the taste of US art film audiences. As for the Hong Kong filmmakers already facing the collapse of their own industry, their style was readily domesticated by a wide range of directors, from Guy Ritchie to Quentin Tarantino, rendering the need for the original less pressing-as seen by the transformation of the Infernal Affairs trilogy (無間道, Lau and Mak, 2002-2003) into The Departed (Scorsese, 2006).

Recently PRC cinema seems to be making a festival comeback: Jia Zhangke and to an extent Lou Ye are certainly among the major festival filmmakers working today, despite the fact that neither has had a success that has crossed over to larger audiences. Hu Bo's enormously impressive An Elephant Sitting Still (大象席地而坐, 2018), the films of Bi Gan, and Diao Yinan's The Wild Goose Lake (南方車站的聚會, 2019) have all 
made the trek from festival appearances to the dwindling art-house circuit. I watched a wonderful film, Gu Xiaogang's debut Dwelling in the Fuchun Mountains (春江水暖, 2019), in Paris, where it generated much critical interest (see figures 3, 4, and 5).

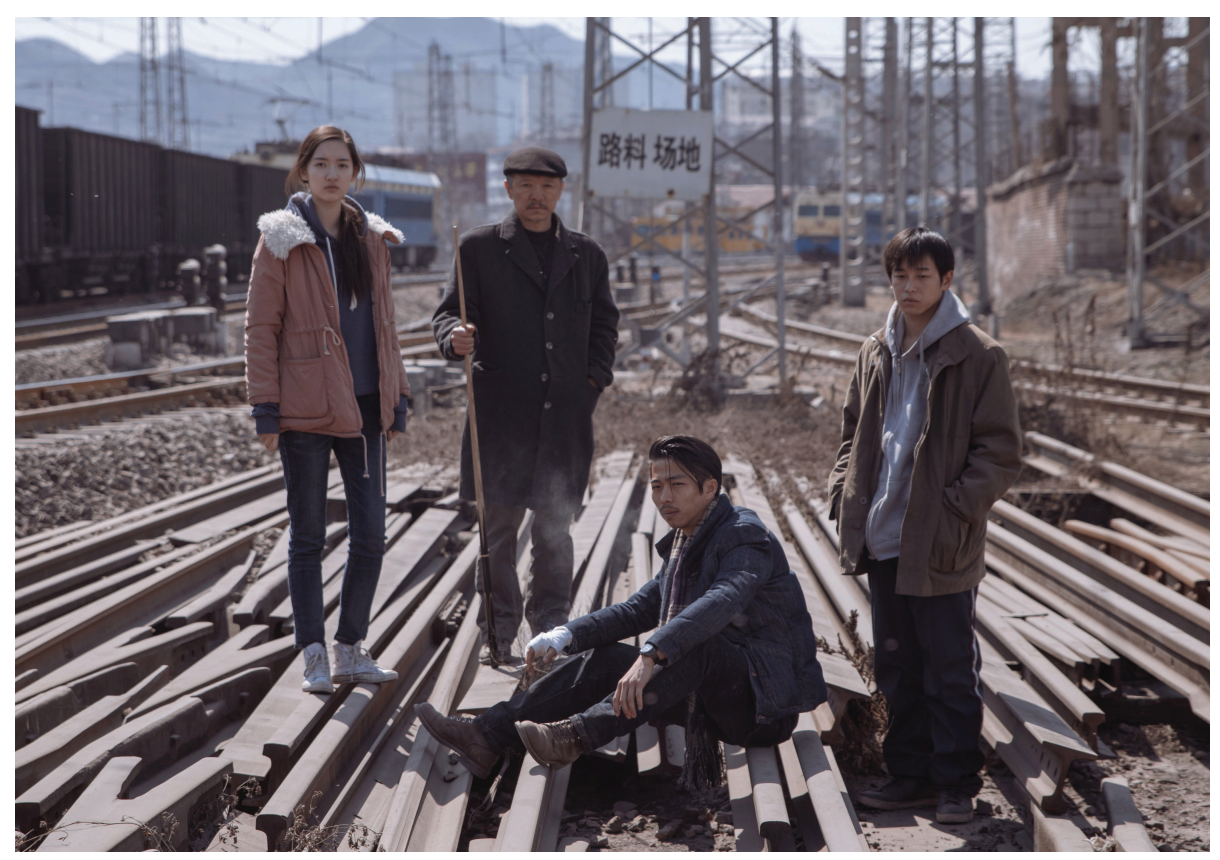

Figure 5.3: Film still of An Elephant Sitting Still. Source: fair use

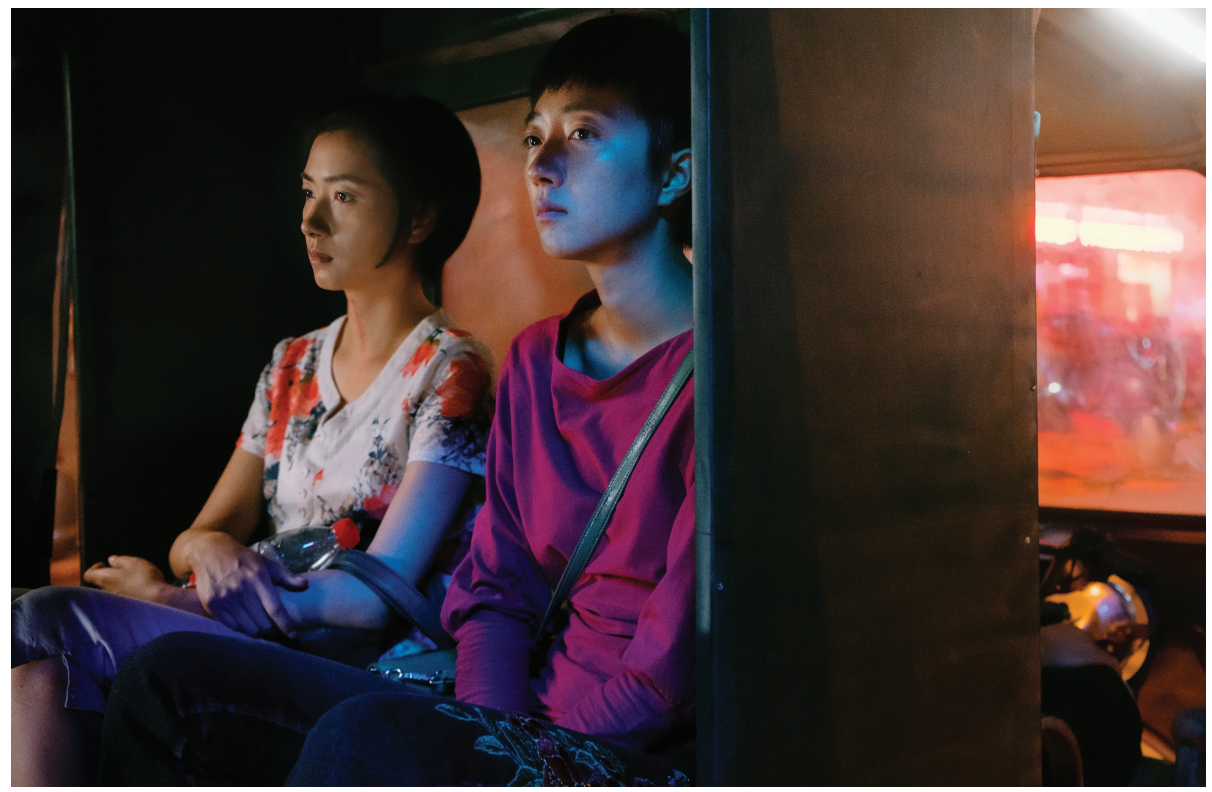

Figure 5.4: Film still of The Wide Goose Lake. Source: fair use 


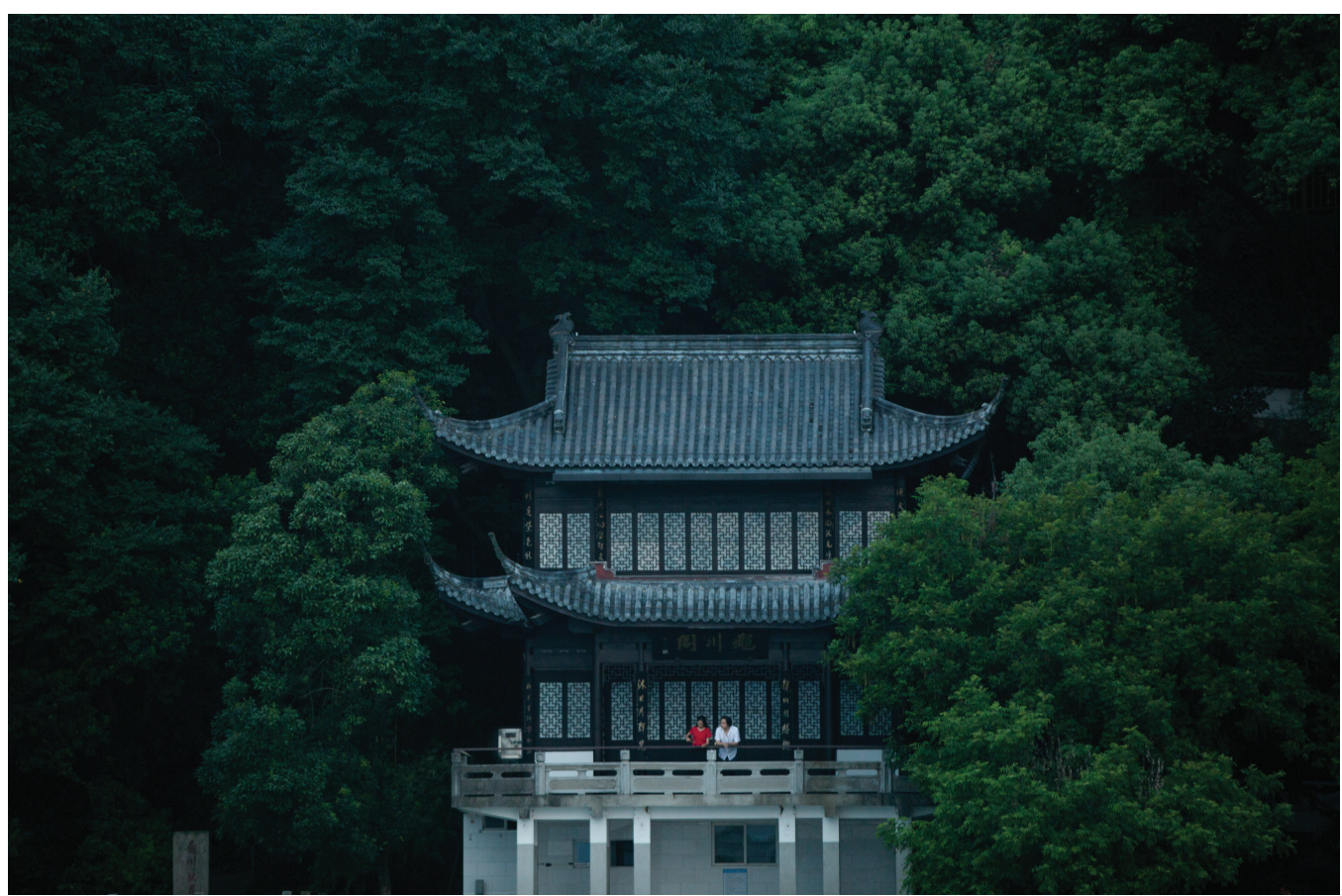

Figure 5.5: Film still of Dwelling in the Fuchun Mountains. Source: fair use

All of these are films that had a major festival premiere, from which they moved on to other festivals and, in most cases, to the art-house circuit. It's an old pattern, and one whose demise keeps being predicted, yet, as we head into our third decade of the twenty-first century, it's a means that the Chinese-from the PRC, Taiwan, and Hong Kong-continue to use effectively to market their films to the world. 